\title{
PUBLIC PROCUREMENT REGULATION IN AFRICA BIBLIOGRAPHY
}

\author{
APPRRU
}

\section{(2014) 1 APPLJ 107}

This bibliography lists all academic materials published in English on matters relating to public procurement law in Africa. It is up to date to 1 February 2015. 


\section{PUBLIC PROCUREMENT REGULATION IN AFRICA BIBLIOGRAPHY}

\section{FEBRUARY 2015}

DEVELOPED AND MAINTAINED BY THE

AFRICAN PUBLIC PROCUREMENT REGULATION RESEARCH UNIT (APPRRU)

www.sun.ac.za/procurementlaw

MATERIAL ON REGIONAL ARRANGEMENTS AND OTHER GENERAL /

COMPARATIVE MATERIAL

\section{GENERAL / COMPARATIVE}

\section{Articles and Essays in Edited Collections}

B. Basheka, "Public Procurement Reforms in Africa: A Tool for Effective Governance and the Public Sector and Poverty Reduction" in K.V. Thai, (ed.), International Handbook of Public Procurement (Boca Raton, FL: Taylor and Francis, 2009) 131

E. Caborn \& S. Arrowsmith, "Procurement Methods in Public Procurement Systems in Africa" in G. Quinot \& S. Arrowsmith (eds) Public Procurement Regulation in Africa (Cambridge University Press, 2013) 331

A. Fall and M. Frilet, "Public Procurement in Francophone Africa" in R. Hérnandez Garcia (ed.), International Public Procurement: a Guide to Best Practice (Globe Law and Business, 2009) 75

K. Jacobs, "Naval Programmes - Procurement Programmes of Middle-East and NorthAfrican Navies" (2007) 27 Naval Forces 83

S.R. Karangizi, "Framework Arrangements in Public Procurement: A Perspective from Africa" in S. Arrowsmith (ed.), Reform of the UNCITRAL Model Law on Procurement: Procurement Regulation for the 21st Century (Eagan: West, 2009) 243

J.O. Kuye \& U. Kakumba, "The Ombudsman Institutions in the Procurement of Legal Responsibilities in the Commonwealth: An Overview of Canada, South Africa and Uganda" (2008) 43(3) Journal of Public Administration 156

A. La Chimia, "The Impact of Aid-Funded Procurement on National Procurement Systems in Africa: A Theoretical View" in G. Quinot \& S. Arrowsmith (eds) Public Procurement Regulation in Africa (Cambridge University Press, 2013) 284

F. Lichere \& B. Martor, "On the Development of Public-Private Partnerships in Africa: Current Reforms and Future Prospects" (2007) 3 International Business Law Journal 297

G. Quinot, "A Comparative Perspective on Supplier Remedies in African Public Procurement Systems" in G. Quinot \& S. Arrowsmith (eds) Public Procurement Regulation in Africa (Cambridge University Press, 2013) 390

G. Quinot "Promotion of Social Policy through Public Procurement in Africa" in G. Quinot \& S. Arrowsmith (eds) Public Procurement Regulation in Africa (Cambridge University Press, 2013) 467

G. Quinot \& S. Arrowsmith, "Introduction" in G. Quinot \& S. Arrowsmith (eds) Public Procurement Regulation in Africa (Cambridge University Press, 2013) 1

S. Willet, "Defence Expenditures, Arms Procurement and Corruption in Sub-Saharan Africa" (2009) 36 Review of African Political Economy 335 
S. Williams-Elegbe, "The Changes to the World Bank's Procurement Policy and the Implications for African Borrowers" (2014) 1 African Public Procurement Law Journal 22 (http://dx.doi.org/10.14803/1-1-3)

S. Williams-Elegbe, "Beyond UNCITRAL: The challenges of procurement reform implementation in Africa" (2014) 25 Stellenbosch Law Review 209-224

S. Williams-Elegbe, "A Perspective on Corruption and Public Procurement in Africa" in G. Quinot \& S. Arrowsmith (eds) Public Procurement Regulation in Africa (Cambridge University Press, 2013) 425

\section{Notes}

W. Odhiambo, \& P. Kamau, "Public Procurement: Lessons from Kenya, Tanzania and Uganda" (OECD Development Centre, 2006) [http://www.oecd-

ilibrary.org/docserver/download/fulltext/5lgsjhvj7843.pdf?expires $=1289653149 \& \mathrm{id}=0000$ \&accname=guest \&checksum $=21011$ C9633AD1509062E3309A11D170B]

Report on the Proceedings of the Conference of the Public Procurement Reform in Africa, Abijan 1998 (The World Bank, The African Development Bank, United Nations Development Programme, International trade Centre UNCTAD/WTO, 1998)

\section{COMMON MARKET FOR EASTERN AND SOUTHERN AFRICA (COMESA)}

\section{Articles and Essays in Edited Collections}

S.R. Karangizi, "The Comesa Public Procurement Reform Initiative" (2005) 14 Public Procurement Law Review

S.R. Karangizi and I. Ndahiro, "Public Procurement Reform and Development in the Eastern and Southern Africa Region" in R. Hérnandez Garcia (ed.), International Public Procurement: a Guide to Best Practice (Globe Law and Business, 2009) 113

E. Nwogwugwu, "Towards the Harmonisation of International Procurement Policies and Practices" (2005) 14 Public Procurement Law Review 131

\section{ORGANISATION FOR THE HARMONISATION OF BUSINESS LAW IN AFRICA (L'ORGANISATION POUR I'HARMONISATION DU DROIT DES AFFAIRES EN AFRIQUE - OHBLA)}

\section{Articles and Essays in Edited Collections}

O. Fille-Lambie, "Legal Aspects of Project Financing as Applied to Public Utilities in the Ohbla Zone" (2001) International Business Law Journal 925

\section{Notes}

P.K. Agboyibor, "Ohbla - Business Law in Africa" (2000) International Business Law Journal 490

\section{MATERIAL ON INDIVIDUAL COUNTRIES}

\section{BOTSWANA}

\section{Articles and Essays in Edited Collections}

R. Kumar \& E. Caborn, "The Regulatory Framework for Public Procurement in Botswana" in G. Quinot \& S. Arrowsmith (eds) Public Procurement Regulation in Africa (Cambridge University Press, 2013) 28 


\section{EGYPT}

\section{Articles and Essays in Edited Collections}

M.A.M. Ismail, "Legal Globalization and PPPs in Egypt: An Analytical and Comparative Perspective on the Current Legislative and Judicial Modifications to and Enhancements of the Administrative Contractual Regime on PPP Transactions" (2010) 5 European Public Private Partnership Law 54

A.Y. Zohny, "Egypt's Procurement Regime and Building an Export Oriented Economy" (2003) 18 Arab Law Quarterly 169

\section{ETHIOPIA}

\section{Articles and Essays in Edited Collections}

T.H. Bahta, "Adjudication and Arbitrability of Government Construction Contract Disputes in Ethiopia" (2009) 3 Mizan Law Review 1

T.H. Bahta, "The Regulatory Framework for Public Procurement in Ethiopia" in G. Quinot \& S. Arrowsmith (eds) Public Procurement Regulation in Africa (Cambridge University Press, 2013) 56

D. Rene, "Administrative Contracts in The Ethiopian Civil Code" Vol iv(1) Journal of Ethiopian Law 143 (translated into English by Michael Kindred)

\section{GAMBIA}

\section{Articles and Essays in Edited Collections}

W.A. Wittig \& H. Jeng, "Challenges in Public Procurement: Comparative Views of Public Procurement Reform in Gambia" in K.V. Thai, et al (eds.) Challenges in Public Procurement: An International Perspective (Volume 3) (Boca Raton, FL: PrAcademics Press, 2005) 21

\section{GHANA}

\section{Books}

D.N. Dagbanja, The Law of Public Procurement in Ghana (Saarbrücken: LAP Lambert Academic Publishing, 2011)

\section{Articles and Essays in Edited Collections}

D.N. Dagbanja "The Regulatory Framework for Public Procurement in Ghana" in G. Quinot \& S. Arrowsmith (eds) Public Procurement Regulation in Africa (Cambridge University Press, 2013) 95

D. Ofosu-Dorte, I. Boaten \& F. Adadzi "Ghana" in H-J. Prieß, (ed.), Getting the Deal Through: Public Procurement 2010 (London: Law Business Research Ltd, 2010) 115 R. Verhage, J. v.d. Gronden, K. Awanyo \& S. Boateng, "Procurement Reform in the Ghana Health Sector" (2002) 2 Journal of Public Procurement 261 


\section{KENYA}

\section{Articles and Essays in Edited Collections}

A.J.M. Migai, "Development Partners and Governance of Public Procurement in Kenya: Enhancing Democracy in the Administration of Aid" (2005) 37 New York University Journal of International Law and Politics 829

V. Mosoti, "Reforming the Laws on Public Procurement in the Developing World: The Example of Kenya" (2005) 54 International Commercial Law Quarterly 621

M. Nyaoga \& C. Odhiambo, "Kenya" in H-J. Prieß, (ed.), Getting the Deal Through: Public Procurement 2010 (London: Law Business Research Ltd, 2010) 152 M. Nyaoga \& C. Odhiambo, "Kenya" in H-J. Priess, (ed.), Getting the Deal Through: Public Procurement 2009: Public Procurement: an Overview of Regulation in 43 Jurisdictions Worldwide (London: Law Business Research Ltd, 2009) 136 M. Ogot, M. Mulinge and R. Muriuki, "Impact of Public Procurement Law in ProfitOriented State-Owned Corporations in Kenya" in K.V. Thai (ed.), Towards New Horizons in Public Procurement (Florida: PrAcademics Press, 2010) 372

K.T. Udeh "The Regulatory Framework for Public Procurement in Kenya" in G. Quinot \& S. Arrowsmith (eds) Public Procurement Regulation in Africa (Cambridge University Press, 2013) 126

K.T. Udeh "A Critical Appraisal of Kenya's Supplier Review System in the Light of International Standards" (2013) 22 Public Procurement Law Review 183

\section{Notes}

J.M.M. Akech, "Development Partners and Governance of Public Procurement in Kenya: Enhancing Democracy in the Administration of Aid" (2006) 3 International Law and Justice Working Paper [Global Administrative Law Series www.iilj.org]

\section{LESOTHO}

\section{Articles and Essays in Edited Collections}

F. Darroch, "The Lesotho Corruption Trials - A Case Study" (2003) 29 Commonwealth Law Bulletin 901

\section{LIBERIA}

\section{Articles and Essays in Edited Collections}

D. Ofosu-Dorte, I. Boaten \& F. Adadzi "Liberia" in H. Prieß, (ed.), Getting the Deal

Through: Public Procurement 2010 (London: Law Business Research Ltd, 2010) 163

\section{MALI}

\section{Notes}

J. Ruche \& E. Garandeau, "The Mali Donors' Public Procurement Procedures: Towards Harmonisation with the National Law 6 (2000)", available at http:// webdomino1.oecd.org/COMNET/DCD/ProcurementCWS.nsf/viewHtml/index/\$FILE/1_ MaliProcurement-website.pdf. 


\section{NAMIBIA}

\section{Articles and Essays in Edited Collections}

S.K. Amoo \& S. Dicken "The Regulatory Framework for Public Procurement in Namibia" in G. Quinot \& S. Arrowsmith (eds) Public Procurement Regulation in Africa (Cambridge University Press, 2013) 156

\section{Notes}

F. Links \& C. Daniels "The Tender Board: Need for Root and Branch Reform" AntiCorruption Research Programme Paper 3 (2011)

E. Tjirera "Public Procurement in Namibia: The Role of Codes of Conduct in Reducing Corruption" Anti-Corruption Research Programme Paper 3 (2011)

\section{NIGERIA}

\section{Articles and Essays in Edited Collections}

A.J. Osuntogun, "Procurement Law in Nigeria: Challenges in Attaining its Objectives" (2012) 21 Public Procurement Law Review 139

G. Oyebode \& O. Fayokun, "Nigeria" in H-J. Prieß, (ed.), Getting the Deal Through:

Public Procurement 2010 (London: Law Business Research Ltd, 2010) 185

O. Soyeju, "Legal framework for public private partnership in Nigeria" (2013) 46 De Jure 814

K.T. Udeh \& L. Ahmadu "The Regulatory Framework for Public Procurement in Nigeria" in G. Quinot \& S. Arrowsmith (eds) Public Procurement Regulation in Africa (Cambridge University Press, 2013) 182

S. Williams, "The Development of Defence Procurement Policy in Nigeria and the Case for Reform" (2005) 14 Public Procurement Law Review 153

S. Williams-Elegbe, "The Reform and Regulation of Nigerian Public Procurement" (2011) 41 Public Contract Law Journal 339

\section{Notes}

S. Ekpenkhio, "Public Sector Procurement Reforms: The Nigerian Experience" paper presented to Regional Workshop on Procurement Reforms and Transparency in Government Procurement for Anglophone Countries, Tanzania, January 16, 2003

\section{RWANDA}

\section{Articles and Essays in Edited Collections}

I. Rugema "The Regulatory Framework for Public Procurement in Rwanda" in G. Quinot \& S. Arrowsmith (eds) Public Procurement Regulation in Africa (Cambridge University Press, 2013) 210

F. Zigirinshuti, "Rwanda" in R. Noguellou \& U. Stelkens, (eds.), Droit comparé des Contrats Publics/ Comparative Law on Public Contracts (Brussels: Bruylant, 2010) 858 


\section{SOUTH AFRICA}

\section{Books}

A.M. Anthony, The legal regulation of construction procurement in South Africa, (2013), LLM thesis, Stellenbosch: Stellenbosch University

P. Bolton, The Law of Government Procurement in South Africa (Durban: LexisNexis Butterworths, 2007)

S.P. le R. de la Harpe, Public Procurement Law: A Comparative Analysis, (2009), LLD thesis, University of South Africa (http://uir.unisa.ac.za/handle/10500/3848)

T.E. Manchidi \& I. Hammond, Targeted Procurement in the Republic of South Africa: An Independent Assessment (International Labour Organisation, 2002)

G. Quinot, State Commercial Activity: A Legal Framework (Cape Town: Juta \& Co, 2009) J. Sylvester, Legislative Control over the Military: A Critical Analysis of the Strategic Arms Package, (2006), MA thesis, Cape Town: University of Cape Town

\section{Articles and Essays in Edited Collections}

P. Bolton, "Disqualification for non-compliance with public tender conditions" (2014) 17(6) Potchefstroom Electronic Law Journal 2314

(http://dx.doi.org/10.4314/pelj.v17i6.03)

P. Bolton, "An Analysis of the Criteria Used to Evaluate and Award Public Tenders" (2014) Speculum Juris 1 (http://www.speculumjuris.co.za/files/pdf/SJ0714P.pdf)

P. Bolton, "The Regulatory Framework for Public Procurement in South Africa" in G. Quinot \& S. Arrowsmith (eds) Public Procurement Regulation in Africa (Cambridge University Press, 2013) 232

P. Bolton, "Municipal Tender Awards and Internal Appeals by Unsuccessful Bidders" (2010) 13:3 Potchefstroom Electronic Law Journal 1

P. Bolton, "The Regulation of Preferential Procurement in State-owned Enterprises" (2010) Journal of South African Law 101

P. Bolton, "Afrique du Sud/South Africa" in R. Noguellou \& U. Stelkens, (eds.), Droit comparé des Contrats Publics/ Comparative Law on Public Contracts (Brussels:

Bruylant, 2010) 281

P. Bolton, "South Africa" in H-J. Prieß, (ed.), Getting the Deal Through: Public

Procurement 2010 (London: Law Business Research Ltd, 2010) 227

P. Bolton, "Overview of the Government Procurement System in South Africa" in K.V. Thai, (ed.), International Handbook of Public Procurement (Boca Raton, FL: Taylor and Francis, 2009) 357

P. Bolton, "The Status of Contracts Exceeding a Municipal Tender Call" 2009 Journal of South African Law 382

P. Bolton, "The Committee System for Competitive Bids in Local Government" (2009) 12(2) Potchefstroom Electronic Law Journal 56

P. Bolton, "Protecting the Environment through Public Procurement: the Case of South Africa" (2008) 32(1) Natural Resources Forum 1

P. Bolton, "Incorporating Environmental Considerations into Government Procurement in South Africa" 2008 Journal of South African Law 31

P. Bolton, "The Public Procurement System in South Africa: Main Characteristics" (2008)

37 Public Contract Law Journal 781

P. Bolton, "An Analysis of the Preferential Procurement Legislation in South Africa"

(2007) 16 Public Procurement Law Review 36

P. Bolton, "The Exclusion of Contractors from Government Contract Awards" (2006) 10

Law, Democracy and Development 25 
P. Bolton, "Grounds for Dispensing with Public Tender Procedures in Government Contracting" (2006) 9(2) Potchefstroom Electronic Law Journal 1

P. Bolton, "Scope for Negotiating and / or Varying the Terms of Government Contracts Awarded by Way of a Tender Process" (2006) 17 Stellenbosch Law Review 266

P. Bolton, "Government Procurement as a Policy Tool in South Africa" (2006) 6 Journal of Public Procurement 193

P. Bolton, "Government Contracts and the Fettering of Discretion - A Question of Validity" (2004) 19 South African Public Law 90

P. Bolton, "Government Dealings and the Intention to Create Legal Relations" (2004) 16 South African Mercantile Law Journal 196

P. Bolton, "The Use of Government Procurement as an Instrument of Policy" (2004) 121 South African Law Journal 619

P. Bolton \& G. Quinot, "Social Policies in Procurement and the Government Procurement Agreement: a Perspective from South Africa" in S. Arrowsmith \& R.D. Anderson (eds) The WTO Regime on Government Procurement: Recent Developments and Challenges Ahead (Cambridge University Press, 2011) 459

D.C. Campbell, "US Firms and Black Labour in South Africa: Creating a Structure of Change" (1986) 7 Journal of Labour Research 1

D.D. Caron, "The Structure and Pathologies of Local Selective Procurement Ordinances:

A Study of Apartheid-Era South Africa Ordinances" (2003) 21 Berkeley Journal of International Law 159

S. De la Harpe, "Green Public Procurement - An Option for South Africa?" (2008) 22

Speculum Juris 53

G. Devenish, "The Legal and Constitutional Position of the Tender Board in KwaZulu-

Natal and Related matters" 1998 Journal of South African Law 398

J. Dohrman \& J. Aiello, "Public-Private Partnerships for Waste Management: Challenges for Policies and Procedures" (1999) 16 Development South Africa 691

C. Ferreira "The Quest for Clarity: An Examination of the Law Governing Public Contracts" (2011) 128 South African Law Journal 172

R. Ferreira \& I. Liebenberg, "Civil-Military Relations and arms Procurement in South Africa: 1994-2002" (2004) 35 Society in Transition 61

B.M. Jackson \& M. Hlahla, "South Africa's Infrastructure Delivery Needs: The Role and Challenge for Public-Private Partnerships" (1999) 16 Development South Africa 551

J-P. Labuschagne, "Public-Private Partnerships in the Health Industry" (1998) 15

Development South Africa 133

D. Letchmiah, "The Process of Public Sector Procurement Reform in South Africa" (1999) 8 Public Procurement Law Review 15

C. McCrudden, "Social Policy Choices and the International and National Law of Government Procurement: South Africa as a Case Study" in H. Corder, (ed.), Global Administrative Law (Cape Town: Juta \& Co, 2009) 123

J.C. Pauw \& J.S. Wolvaardt, "Multi-criteria Decision Analysis in Public Procurement - A Plan from the South" (2009) 28 Politeia 66

G. Penfold, and P. Reyburn, "Public Procurement" in S. Woolman, T. Roux, J. Klaaren, A. Stein, M. Chaskalson and M. Bishop, (eds.), Constitutional Law of South Africa 2 ed (Cape Town: Juta \& Co, 2008) 25-1

C. Plasket, "Tendering for Government Contracts: Public Procurement and Judicial

Review" in G. Glover, (ed.), Essays in Honour of AJ Kerr (Durban: LexisNexis

Butterworths, 2006) 159

G. Quinot "The Role of Quality in the Adjudication of Public Tenders" (2014) 17:3

Potchefstroom Electronic Law Journal 1110 (http://dx.doi.org/10.4314/pelj.v17i3.08)

G. Quinot "Enforcement of Procurement Law from a South African Perspective" (2011)

20 Public Procurement Law Review 193 
G. Quinot, "Towards Effective Judicial Review of State Commercial Activity" (2009) Journal of South African Law 436

G. Quinot, "Worse than Losing a Government Tender: Winning It" (2008) 19

Stellenbosch Law Review 101

R. Roos \& S. De La Harpe, "Good Governance in Public Procurement: A South African Case Study" (2008) 11(2) Potchefstroom Electronic Law Journal 1

C.Scott \& P. Macklem, "Constitutional Ropes of Sand or Justiciable Guarantees? Social Rights in a New South African Constitution" (1992) 141 University of Pennsylvania Law Review 1

M. Sinclair, "Regulation and Facilitation of Public-Private Partnerships: the MSP Policy" (1999) 16 Development Southern Africa 585

J.C. Sonnekus, "Procurement contracts and underlying principles of the law - no special dispensation for organs of state (part 1 - the principles)" 2014 Journal of South African Law 320

J.C. Sonnekus, "Procurement contracts and underlying principles of the law - no special dispensation for organs of state (part 2 - developing the common law, consequences and remedies)" 2014 Journal of South African Law 536

N. Steytler, and J. De Visser, Local Government Law of South Africa (Durban:

LexisNexis Butterworths, 2007) chapter 14

J. Sylvester \& A. Seegers, "South Africa's strategic arms package: a critical analysis" (2008) 36:1 Scientia Militaria 52-77

H. Van As, "The Right to Information and the Tender Process" (1999) 34 Journal of

Public Administration 257

K. Van Vuuren \& J.A. Badenhorst-Weiss, "South African Provincial Government Reform: Using a Shared Services Model to Transform 'Back-Office' Support in Gauteng Province" in L. Knight, C. Harland, J. Telgen, K.V. Thai, G. Callender \& K. McKen (eds.), Public Procurement: International Cases and Commentary (London: Routledge, 2007) 278

P. Volmink, "Legal consequences of non compliance with bid requirements" (2014) 1 African Public Procurement Law Journal 41 (http://dx.doi.org/10.14803/1-1-4) R. Watermeyer, "The Use of Targeted Procurement as an Instrument of Poverty Alleviation and Job Creation in Infrastructure Projects" (2000) 9 Public Procurement Law Review 226

R. Watermeyer, "Facilitating Sustainable Development through Public and Donor Procurement Regimes: Tools and Techniques" (2004) 13 Public Procurement Law Review 30

S. Williams, \& G. Quinot, "Public Procurement and Corruption: The South African Response" (2007) 124 South African Law Journal 339

S. Williams, \& G. Quinot, "To Debar or not to Debar: When to Endorse a Contractor on the Register for Tender Defaulters" (2008) 125 South African Law Journal 248

S. Williams, "The Use of Exclusions for Corruption in Developing Country Procurement: The Case of South Africa" (2007) 51 Journal of African Law 1

\section{Notes}

P. Bolton, "New Preferential Procurement Regulations Released" (2011) 13 Local Government Bulletin 7

P. Bolton, "Tender Awards in the Spotlight: Limitations of Internal Appeal Procedures" (2010) 12(3) Local Government Bulletin 18

P. Bolton, "The Different Hats Warn by the Municipal Manager in the Tender / Bid

Process" (2010) 12(2) Local Government Bulletin 10 
P. Bolton, "Checks and Balances: Service Delivery by External Providers" (2010) 12(1) Local Government Bulletin 15

P. Bolton, "Notifying the Correct Bidder of its Success" (2009) 11(5) Local Government Bulletin 25

P. Bolton, "The Roles and Functions of Bid Committees" (2009) 11(4) Local Government Bulletin 19

P. Bolton, "The Municipal Manager's Supervisory Role over Bid Committees" (2009)

11(2) Local Government Bulletin 26

P. Bolton, "When can Bidders with Bad Track Records be Rejected?" (2009) 11(1) Local Government Bulletin 22

P. Bolton, "Who Excludes Bidders from Future Contracts?" (2008) 10(5) Local

Government Bulletin 22

P. Bolton, "Supply Chain Management and Public-Private Partnership Provisions" (2004)

6(4) Local Government Bulletin 4

B.M. Jackson, \& M. Hlahla, "South Africa's Infrastructure Service Delivery Needs: The Role and Challenge for Public-Private Partnerships" (1999)16 Development Southern Africa 1

V. Johnson, "Service Delivery Agreements: Who Reads Them?" (2005) 7(2) Local Government Bulletin 7

G. Mawoneke, "The PPP Procurement Process" (2005) 7(3) Local Government Bulletin 11

D. McMeekin, "State Procurement: The Public / Private Divide" 2009 Responsa Meridiana 35

A. Molver \& K. Harding "The Procurement Dilemma at the End of the Rainbow" (February 2014) Without Prejudice 40

N. Muvangua, "Tokenism and the Constitutional Court Finding on Viking Pony Africa Pumps Africa and Hidro-Tech Systems (Pty) Ltd and City of Cape Town" 2010 (Center for Constitutional Rights) http://www.polity.org.za/article/okenism-and-the-constitutionalcourt-finding-on-viking-pony-africa-pumps-pty-Itd-ta-tricom-africa-and-hidro-techsystems-pty-ltd-and-city-of-cape-town-2010-11-29

G. Quinot, "The Need for Unified Legislation in Public Procurement" 2014

SmartProcurement Review 36

G. Quinot, "Public Procurement" 2014 Juta's Quarterly Review of South African Law

G. Quinot, "Public Procurement" 2013 Juta's Quarterly Review of South African Law

G. Quinot, "Public Procurement" 2012 Juta's Quarterly Review of South African Law

G. Quinot, "Public Procurement" 2011 Juta's Quarterly Review of South African Law

G. Quinot, "Public Procurement" 2010 Juta's Quarterly Review of South African Law

G. Quinot, "Public Procurement" 2009 Juta's Quarterly Review of South African Law

G. Quinot, "Public Procurement" 2008 Juta's Quarterly Review of South African Law

F. Venter, "Competitive Tendering: A Perspective on PPP / PFI from the Mangaung Maximum Security Prison, South Africa" (2003) Prison Service Journal 149

P.J. Visser, "Damages Recoverable for Prospective Loss of Profit Caused by nonawarding of a tender - Transnet Ltd v Sechaba Photoscan (Pty) Ltd 20051 SA 299 (SCA)" (2005) 68 Journal of Contemporary Roman Dutch Law 510

\section{SIERRA LEONE}

\section{Notes}

F.J. Elliott, "Procurement Reform in Sierra Leone: A Public Choice Model of Analysis" (2004) 3 International Public Procurement Conference Proceedings 189 


\section{UGANDA}

\section{Books}

F. Ssenego, Discriminatory Public Procurement Policies, (2010), PhD Thesis, University of Twente

\section{Articles and Essays in Edited Collections}

E. Agaba \& N. Shipman, "Procurement Systems in Uganda' in K.V. Thai, (ed.), International Handbook of Public Procurement (Boca Raton, FL: Taylor and Francis, 2009) 393

B.C. Basheka, M. Tumutegyereize and E. Agaba "Public Procurement Capacity Building Reform Initiatives in Uganda: A Performance Measurement Approach" in K.V. Thai (ed.), Towards New Horizons in Public Procurement (Boca Raton, FL: PrAcademics Press, 2010) 60

J.M. Ntayi, I. Namugenyi and S Eyeaa, "Supplier Delivery Performance in Ugandan Public Procurement Contracts" (2010) 4 Journal of Public Procurement 479 N. Shipman \& E. Agaba, "Public Procurement Reform in Developing Countries: The Uganda Experience", ch.16 in G. Piga and K.V. Thai (eds), Advancing Public Procurement: Practices, Innovation and Knowledge-sharing (Boca Raton, FL:

PrAcademics Press, 2007) 373

\section{ZIMBABWE}

\section{Articles and Essays in Edited Collections}

J. Zowa, N. Machingauta \& P. Bolton "The Regulatory Framework for Public Procurement in Zimbabwe" in G. Quinot \& S. Arrowsmith (eds) Public Procurement Regulation in Africa (Cambridge University Press, 2013) 260 J. Tsabora, "Public Procurement in Zimbabwe: Law, Policy and Practice" (2014) 1 African Public Procurement Law Journal 1 (http://dx.doi.org/10.14803/1-1-2) 